\title{
Bridging Hydrogen Atoms Versus Iron-Iron Multiple Bonding in Binuclear Borole Iron Carbonyls
}

\author{
Jianlin Chen, ${ }^{\mathrm{a}}$ Liu Zhong, ${ }^{\mathrm{a}}$ Hao Feng, ${ }^{\mathrm{a} *}$ \\ Yaoming Xie, ${ }^{b}$ and R. Bruce King ${ }^{a, b *}$ \\ ${ }^{a}$ School of Science, Research Center for Advanced Computation, Xihua \\ University, Chengdu, China 610039 \\ ${ }^{b}$ Department of Chemistry and Center for Computational Chemistry \\ University of Georgia, Athens, Georgia 30602, USA \\ E-mail: fenghao@mail.xhu.edu.cn,rbking@chem.uga.edu
}

\begin{abstract}
The geometries and energetics of the binuclear unsubstituted borole iron carbonyls $\left(\mathrm{C}_{4} \mathrm{H}_{4} \mathrm{BH}\right)_{2} \mathrm{Fe}_{2}(\mathrm{CO})_{n}(n=5,4,3,2,1)$ have been studied by density functional theory for comparison with the previously studied related substituted borole iron carbonyls $\left(\mathrm{C}_{4} \mathrm{H}_{4} \mathrm{BR}\right)_{2} \mathrm{Fe}_{2}(\mathrm{CO})_{n}\left[\mathrm{R}=\mathrm{CH}_{3},\left(\mathrm{CH}_{3}\right)_{2} \mathrm{~N}\right]$ having different substituents on the boron atoms. The lowest energy $\left(\mathrm{C}_{4} \mathrm{H}_{4} \mathrm{BH}\right)_{2} \mathrm{Fe}_{2}(\mathrm{CO})_{n}(n=5,4,3)$ structures have terminal borole ligands related to those in the $\left(\mathrm{C}_{4} \mathrm{H}_{4} \mathrm{BR}\right)_{2} \mathrm{Fe}_{2}(\mathrm{CO})_{n}\left[\mathrm{R}=\mathrm{CH}_{3},\left(\mathrm{CH}_{3}\right)_{2} \mathrm{~N}\right]$ systems as well the isoelectronic $\left(\eta^{5}-\mathrm{C}_{5} \mathrm{H}_{5}\right)_{2} \mathrm{Mn}_{2}(\mathrm{CO})_{n}$ systems. However, the lowest energy structure of the dicarbonyl $\left(\mathrm{C}_{4} \mathrm{H}_{4} \mathrm{BH}\right)_{2} \mathrm{Fe}_{2}(\mathrm{CO})_{2}$ is an unusual quintet spin state structure with one of the borole ligands bridging the central $\mathrm{Fe}_{2}$ unit by forming a threecenter two-electron $\mathrm{B}-\mathrm{H}-\mathrm{Fe}$ bond to one iron atom as well as functioning as a pentahapto ligand to the other iron atom. For the $\left(\mathrm{C}_{4} \mathrm{H}_{4} \mathrm{BR}\right)_{2} \mathrm{Fe}_{2}(\mathrm{CO})_{n}\left[\mathrm{R}=\mathrm{CH}_{3},\left(\mathrm{CH}_{3}\right)_{2} \mathrm{~N}\right]$ systems the tricarbonyls $(n=3)$ having formal $\mathrm{Fe}=\mathrm{Fe}$ triple bonds of lengths $\sim 2.2 \AA$ analogous to the experimentally known $\left(\eta^{5}-\mathrm{Me}_{5} \mathrm{C}_{5}\right)_{2} \mathrm{Mn}_{2}(\mu-\mathrm{CO})_{3}$ structure appear to be favorable structures. An analogous $\left(\mathrm{C}_{4} \mathrm{H}_{4} \mathrm{BH}\right)_{2} \mathrm{Fe}_{2}(\mu-\mathrm{CO})_{3}$ structure is found for the unsubstituted borole ligand. However, this structure appears to be disfavored relative to disproportionation into $\left(\mathrm{C}_{4} \mathrm{H}_{4} \mathrm{BH}\right)_{2} \mathrm{Fe}_{2}(\mathrm{CO})_{n+1}+\left(\mathrm{C}_{4} \mathrm{H}_{4} \mathrm{BH}\right)_{2} \mathrm{Fe}_{2}(\mathrm{CO})_{n-1}$.
\end{abstract}




\section{Introduction}

One of the central concepts of modern inorganic chemistry is that of a threecenter two-electron (3c-2e) bond. Such bonding was first recognized in diborane after the structure of diborane was shown to be $\mathrm{B}_{2} \mathrm{H}_{4}(\mu-\mathrm{H})_{2}$ with four terminal and two bridging hydrogen atoms (Figure 1) [1]. The bonding of each bridging hydrogen to the central $\mathrm{B}_{2}$ unit of diborane is the prototypical 3c-2e bond involving overlap of an orbital from the bridging hydrogen with an orbital from each of the two boron atoms [2]. The boron atom in the unstable monomeric borane $\left(\mathrm{BH}_{3}\right)$ may be considered as electron deficient or unsaturated since it has only six electrons in its $\mathrm{sp}^{3}$ manifold thereby leaving an empty $\mathrm{p}$ orbital (Figure 1). Dimerization of $\mathrm{BH}_{3}$ to form the stable $\mathrm{B}_{2} \mathrm{H}_{4}(\mu-\mathrm{H})_{2}$ involves overlap of the empty $\mathrm{p}$ orbital of one $\mathrm{BH}_{3}$ unit with the $\mathrm{B}-\mathrm{H} \sigma$-bonding orbital of a second $\mathrm{BH}_{3}$ unit to form the $3 \mathrm{c}-2 \mathrm{e} \mathrm{B}_{2} \mathrm{H}$ bond.

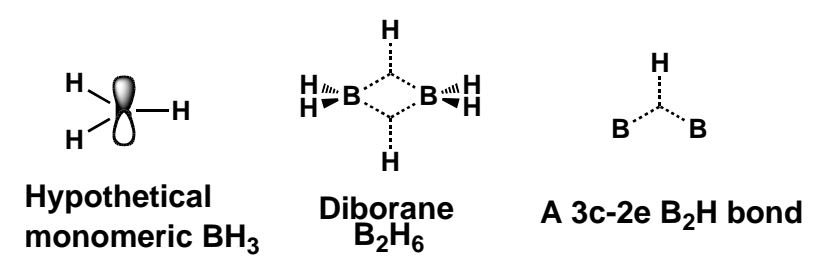

Figure 1. (a) Monomeric $\mathrm{BH}_{3}$ showing the empty p orbital; (2) The doubly bridged structure of diborane, $\mathrm{B}_{2} \mathrm{H}_{4}(\mu-\mathrm{H})_{2}$; (3) The $3 \mathrm{c}-2 \mathrm{e} \mathrm{B}_{2} \mathrm{H}$ bond such as those involving the bridging hydrogens in diborane.

In unsaturated molecules without potentially bridging hydrogens to form multicenter bonds, multiple bonding is another alternative. In metal carbonyl chemistry, the first unsaturated molecule to be synthesized with a metal-metal multiple bond was the pentamethylcyclopentadienylmolybdenum derivative $\left(\eta^{5}-\mathrm{Me}_{5} \mathrm{C}_{5}\right)_{2} \mathrm{Mo}_{2}(\mathrm{CO})_{4}$, obtained by the thermal reaction of $\mathrm{Mo}(\mathrm{CO})_{6}$ with pentamethylcyclopentadiene (Figure 2) [3]. Consideration of the 18 -electron rule suggested a formal $\mathrm{Mo} \equiv \mathrm{Mo}$ triple bond in this species. This suggestion was supported by a subsequent X-ray structural study indicating a short Mo $\equiv$ Mo distance of $2.488 \AA$ as compared with the much longer Mo-Mo single bond distance of $3.235 \AA$ in the otherwise closely related $\left(\eta^{5}-\mathrm{C}_{5} \mathrm{H}_{5}\right)_{2} \mathrm{Mo}_{2}(\mathrm{CO})_{6}$ [4]. Binuclear cyclopentadienylmetal carbonyls subsequently proved to be a fertile source of stable species having multiple bonds between transition metals as exemplified by $\left(\eta^{5}-\mathrm{R}_{5} \mathrm{C}_{5}\right)_{2} \mathrm{Cr}_{2}(\mathrm{CO})_{4} \quad\left(\mathrm{R}=\mathrm{H}\right.$ [5] Me [6,7]), $\left(\eta^{5}-\mathrm{C}_{5} \mathrm{R}_{5}\right)_{2} \mathrm{~V}_{2}(\mathrm{CO})_{5}[8,9]$ and $\left(\eta^{5}-\mathrm{C}_{5} \mathrm{R}_{5}\right)_{2} \mathrm{M}_{2}^{\prime}(\mathrm{CO})_{3}\left(\mathrm{M}^{\prime}=\mathrm{Mn}\right.$ [10] Re [11]) with formal $\mathrm{M} \equiv \mathrm{M}$ triple bonds (Figure 2). In 
addition, $\left(\eta^{5}-\mathrm{C}_{5} \mathrm{H}_{5}\right)_{2} \mathrm{Co}_{2}(\mathrm{CO})_{2}$ [12] and $\left(\eta^{5}-\mathrm{C}_{5} \mathrm{H}_{5}\right)_{2} \mathrm{Fe}_{2}(\mathrm{CO})_{3}$ [13] with formal $\mathrm{M}=\mathrm{M}$ double bonds have been synthesized and characterized structurally (Figure 2). The metal-metal distances in all of these structures with metal-metal multiple bonds were all shown by X-ray crystallography to be significantly shorter than comparable structures clearly indicated to have metal-metal single bonds.

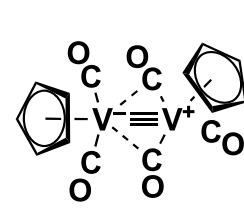

$\mathrm{Cp}_{2} \mathrm{~V}_{2}(\mathrm{CO})_{5}$

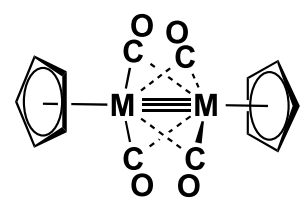

$\mathrm{Cp}_{2} \mathrm{M}_{2}(\mathrm{CO})_{4}$ $(\mathrm{M}=\mathrm{Cr}, \mathrm{Mo})$

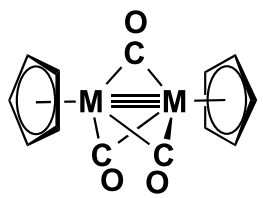

$\mathrm{Cp}_{2} \mathrm{M}_{2}(\mu-\mathrm{CO})_{3}$

$\left(M^{\prime}=M n, R e\right)$

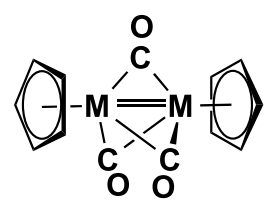

$\mathrm{Cp}_{2} \mathrm{Fe}_{2}(\mu-\mathrm{CO})_{3}$

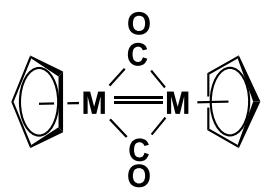

$\mathrm{Cp}_{2} \mathrm{M}_{2}(\mathrm{CO})_{2}$

$(M=C o, R h)$

Figure 2. Known binuclear cyclopentadienylmetal carbonyls with $\mathrm{M} \equiv \mathrm{M}$ triple bonds or $\mathrm{M}=\mathrm{M}$ double bonds.

The unsubstituted borole ligand $\mathrm{C}_{4} \mathrm{H}_{4} \mathrm{BH}$ is of interest in potentially forming transition metal complexes either with a terminal pentahapto borole ligand analogous to the ubiquitous pentahapto cyclopentadienylmetal complexes or species with B-H-M bridges exhibiting $3 \mathrm{c}-2 \mathrm{e}$ BHM bonding analogous to the $3 \mathrm{c}-2 \mathrm{e} \mathrm{B}_{2} \mathrm{H}$ bonding in diborane discussed above. Since the borole ligand can be generated by replacement of one of the five carbon atoms in the neutral cyclopentadienyl ligand with boron, the borole ligand, has one electron less than the cyclopentadienyl ligand. As a result, the neutral borole ligand is a net donor of four $\pi$ electrons to a transition metal system, whereas a neutral cyclopentadienyl ligand is a net donor of five $\pi$ electrons. Thus neutral borole is an antiaromatic $4 n \pi$-electron system similar to cyclobutadiene. For this reason unsubstituted borole, $\mathrm{C}_{4} \mathrm{H}_{4} \mathrm{BH}$, is unstable in the free state and thus not available as a ligand to react directly with transition metal derivatives for the synthesis of its metal complexes. However, borole metal complexes have been synthesized using stable dihydroboroles as starting materials. Such reactions may involve direct thermal reactions of dihydroboroles with metal carbonyls to give complexes such as $\left(\eta^{5}-\mathrm{C}_{4} \mathrm{H}_{4} \mathrm{BR}\right) \mathrm{M}(\mathrm{CO})_{3} \quad(\mathrm{M}=\mathrm{Fe}$ [14], $\mathrm{Ru}$ [15], Os [15]; $\left.\mathrm{R}=\mathrm{CH}_{3}, \mathrm{C}_{6} \mathrm{H}_{5}\right),\left(\eta^{5}-\mathrm{C}_{4} \mathrm{H}_{4} \mathrm{BR}\right)_{2} \mathrm{Co}_{2}(\mathrm{CO})_{2}(\mu-\mathrm{CO})_{2}$ [16] and $\left(\eta^{5}, \eta^{5}-\mu-\right.$ 
$\left.\mathrm{C}_{4} \mathrm{H}_{4} \mathrm{BR}\right)\left[\mathrm{Mn}(\mathrm{CO})_{3}\right]_{2}[14]$. Alternatively, borole dianions, which can be obtained by the dilithiation of dihydroboroles [17], are also possible reagents for the synthesis of borole metal complexes.

The iron derivatives $\left(\eta^{5}-\mathrm{C}_{4} \mathrm{H}_{4} \mathrm{BR}\right) \mathrm{Fe}(\mathrm{CO})_{3}$ are among the most stable and readily synthesized borole metal carbonyl complexes [18]. These are isoelectronic with both cymantrene $\left(\eta^{5}-\mathrm{C}_{5} \mathrm{H}_{5}\right) \mathrm{Mn}(\mathrm{CO})_{3}[19,20]$ and the very stable cyclobutadiene-iron tricarbonyl $\left(\eta^{4}-\mathrm{C}_{4} \mathrm{H}_{4}\right) \mathrm{Fe}(\mathrm{CO})_{3}[21]$. Both of these latter systems are known to undergo photolysis to form binuclear derivatives with metal-metal bonds. Among such derivatives, the binuclear tricarbonyls $\left(\eta^{5}-\mathrm{C}_{5} \mathrm{H}_{5}\right)_{2} \mathrm{Mn}_{2}(\mathrm{CO})_{3}[22]$ and $\left(\eta^{4}-\mathrm{C}_{4} \mathrm{H}_{4}\right)_{2} \mathrm{Fe}_{2}(\mathrm{CO})_{3}[23,24]$ with formal metal-metal triple bonds appear to be the most stable and are readily synthesized. In a previous paper [25] we used density functional theory to explore the potential of analogous binuclear methylborole complexes $\left(\eta^{5}-\mathrm{C}_{4} \mathrm{H}_{4} \mathrm{BCH}_{3}\right)_{2} \mathrm{Fe}_{2}(\mathrm{CO})_{n}(n=$ $5,4,3,2,1)$. To our surprise the methyl hydrogens in the highly unsaturated $\left(\eta^{5}-\mathrm{C}_{4} \mathrm{H}_{4} \mathrm{BCH}_{3}\right)_{2} \mathrm{Fe}_{2}(\mathrm{CO})_{n}(n=2,1)$ were found to form agostic $3 \mathrm{c}-2 \mathrm{e} \mathrm{C}-\mathrm{H}-\mathrm{Fe}$ bonds in low-energy structures (Figure 3). We then used the same theoretical methods to investigate analogous binuclear dimethylaminoborole iron carbonyl complexes $\left[\mathrm{C}_{4} \mathrm{H}_{4} \mathrm{BN}\left(\mathrm{CH}_{3}\right)_{2}\right]_{2} \mathrm{Fe}_{2}(\mathrm{CO})_{n}(n=5,4,3,2,1)$ in order to explore possibilities of coordination of the pendant dimethylamino nitrogen group to the iron atom in unsaturated structures [26]. In this connection energetically competitive $\left[\mathrm{C}_{4} \mathrm{H}_{4} \mathrm{BN}\left(\mathrm{CH}_{3}\right)_{2}\right]_{2} \mathrm{Fe}_{2}(\mathrm{CO})_{n}$ ( $n=4,3,2,1)$ structures were found in which the dimethylaminoborole ligand functions as a six-electron donor bridging the pair of iron atoms. Such a bridging dimethylaminoborole ligand functions as a four-electron donor to one iron atom through pentahapto bonding from its $\mathrm{C}_{4} \mathrm{~B}$ ring and a two-electron donor to the other iron atom through donation from the nitrogen lone pair (Figure 3).

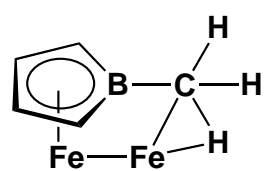

Methylborole: Agostic C-H-Fe

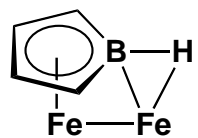

Unsubstituted Borole: B-H-Fe bridge

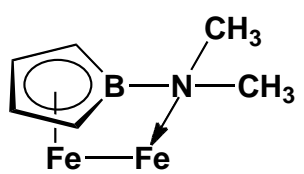

Dimethylaminoborole:

Coordination of

nitrogen lone pair

Figure 3. Six-electron donor borole ligands bridging a pair of iron atoms: involvement of the boron substituent in the ligand-metal bonding.

These studies on binuclear methylborole and dimethylaminoborole iron carbonyl complexes demonstrate that the boron substituents, namely methyl and dimethylamino groups, can bond to the iron atom in unsaturated species (Figure 3). The research reported 
in this paper uses related theoretical methods to explore the formation of $3 \mathrm{c}-2 \mathrm{e} \mathrm{B}-\mathrm{H}-\mathrm{Fe}$ bonds in unsaturated $\left(\mathrm{C}_{4} \mathrm{H}_{4} \mathrm{BH}\right)_{2} \mathrm{Fe}_{2}(\mathrm{CO})_{n}$ species $(n=5,4,3,2,1)$.

\section{Theoretical Methods}

Electron correlation effects were considered by employing density functional theory (DFT) methods, which have evolved as a practical and effective computational tool, especially for organometallic compounds $[27,28,29,30,31,32,33]$. Thus three DFT methods were used in this study. The first functional is the B3LYP method, which is the hybrid HF/DFT method using the combination of the three parameter Becke functional with the Lee-Yang-Parr generalized gradient correlation functional [34, 35]. The other DFT method used in the present paper is BP86, which combines Becke's 1988 exchange functional with Perdew's 1986 gradient corrected correlation functional [36, 37]. Usually the B3LYP and BP86 methods predict consistent geometries and energy orders for the same spin states. However, these two DFT methods often predict different singlet-triplet splittings. The B3LYP method generally favors the high spin state, whereas the BP86 method favors the low spin state. This phenomenon has been thoroughly studied by Reiher and coworkers [38] and is reviewed by Harvey [39]. In order to solve this problem, Reiher et al. proposed a new parametrization for the B3LYP functional, named B3LYP*, which provides electronic state orderings in good agreement with experiment [40].

In the present study, we discuss the B3LYP* energy orderings and geometries in the text. The B3LYP and BP86 results are shown in the Supporting Information. For the $\left(\mathrm{C}_{4} \mathrm{H}_{4} \mathrm{BH}\right)_{2} \mathrm{Fe}_{2}(\mathrm{CO})_{n}(n=5,4)$ systems, the energy orderings from the three methods were in good agreement. For the energy orderings of the more highly unsaturated $\left(\mathrm{C}_{4} \mathrm{H}_{4} \mathrm{BH}\right)_{2} \mathrm{Fe}_{2}(\mathrm{CO})_{n}(n=3,2,1)$ systems having low-energy triplet and quintet spin state structures, the B3LYP method favored the higher spin state structures, the BP86 method favored the lower spin state structures, and the B3LYP* method gave intermediate values in accord with expectation. Since the BP86 $v(\mathrm{CO})$ vibrational frequencies are typically closest to the experimental values without any scaling factors [41, 42, 43], the BP86 method is used to predict the $v(\mathrm{CO})$ frequencies of the species reported in this paper.

All computations were performed using the double- $\zeta$ plus polarization (DZP) basis sets. The DZP basis sets used for boron, carbon and oxygen add one set of pure spherical harmonic $d$ functions with orbital exponents $\alpha_{d}(B)=0.70, \alpha_{d}(C)=0.75$, and $\alpha_{\mathrm{d}}(\mathrm{O})=0.85$ to the standard Huzinaga-Dunning contracted DZ sets [44, 45] and are 
designated ( $9 \mathrm{~s} 5 \mathrm{p} 1 \mathrm{~d} / 4 \mathrm{~s} 2 \mathrm{p} 1 \mathrm{~d})$. For hydrogen, a set of $\mathrm{p}$ polarization functions $\alpha_{\mathrm{p}}(\mathrm{H})=0.75$ is added to the Huzinaga-Dunning DZ set. For iron, our loosely contracted DZP basis set $(14 \mathrm{~s} 11 \mathrm{p} 6 \mathrm{~d} / 10 \mathrm{~s} 8 \mathrm{p} 3 \mathrm{~d})$ uses the Wachters' primitive set [46] augmented by two sets of $\mathrm{p}$ functions and one set of $\mathrm{d}$ functions, contracted following Hood et al. [47]. All optimizations were carried out using the Gaussian 09 program [48] with the fine grid option, i.e., the pruned $(75,302)$ grid, for evaluating integrals numerically.

\section{Results}

\subsection{Molecular Structures}

3.1.1. $\left(\mathrm{C}_{4} \mathrm{H}_{4} \mathrm{BH}\right)_{2} \mathrm{Fe}_{2}(\mathrm{CO})_{5}$. The potential energy surface of $\left(\mathrm{C}_{4} \mathrm{H}_{4} \mathrm{BH}\right)_{2} \mathrm{Fe}_{2}(\mathrm{CO})_{5}$ is fluxional, since four different singlet local minima are found within $6.0 \mathrm{kcal} / \mathrm{mol}$ in energy. All four structures have one bridging $\mathrm{CO}$ group and four terminal groups, i.e., $\left(\mathrm{C}_{4} \mathrm{H}_{4} \mathrm{BH}\right)_{2} \mathrm{Fe}_{2}(\mathrm{CO})_{4}(\mu-\mathrm{CO})$ (Figure 4). The $C_{2}$ trans structure 5S-1 is the global minimum. Two cis $\left(\mathrm{C}_{4} \mathrm{H}_{4} \mathrm{BH}\right)_{2} \mathrm{Fe}_{2}(\mathrm{CO})_{4}(\mu-\mathrm{CO})$ structures, namely 5S-2, and 5S-3, lie 4.9 and $5.7 \mathrm{kcal} / \mathrm{mol}$ (B3LYP*), respectively, in energy above 5S-1. A trans $\left(\mathrm{C}_{4} \mathrm{H}_{4} \mathrm{BH}\right)_{2} \mathrm{Fe}_{2}(\mathrm{CO})_{4}(\mu-\mathrm{CO})$ structure 5S-4 with $\mathrm{C}_{2}$ symmetry lies $6.0 \mathrm{kcal} / \mathrm{mol}(\mathrm{B} 3 \mathrm{LYP} *)$ in energy above 5S-1 (Figure 4). The Fe-Fe distances in all of these singlet singly bridged $\left(\mathrm{C}_{4} \mathrm{H}_{4} \mathrm{BH}\right)_{2} \mathrm{Fe}_{2}(\mathrm{CO})_{4}(\mu-\mathrm{CO})$ structures range from $2.788 \AA$ to $2.863 \AA$ (B3LYP*), consistent with the formal $\mathrm{Fe}-\mathrm{Fe}$ single bond, required to give each $\mathrm{Fe}$ atom the favored 18-electron configuration.

The $v(\mathrm{CO})$ frequencies of the bridging $\mathrm{CO}$ groups fall in the fairly typical range 1807 to $1828 \mathrm{~cm}^{-1}$ (Table 1), which is about $120 \mathrm{~cm}^{-1}$ below the terminal $v(\mathrm{CO})$ frequencies (1948 to $2030 \mathrm{~cm}^{-1}$ ).

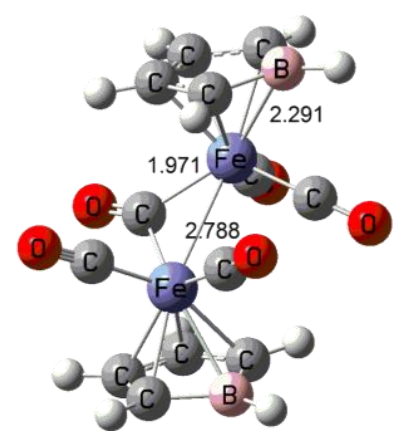

5S-1 $\left(C_{2}, 0.0\right)$

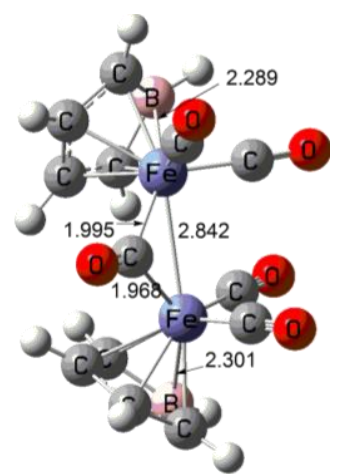

5S-2 $\left(C_{1}, 4.9\right)$

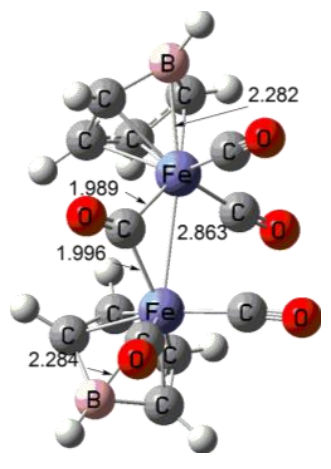

5S-3 $\left(C_{1}, 5.7\right)$

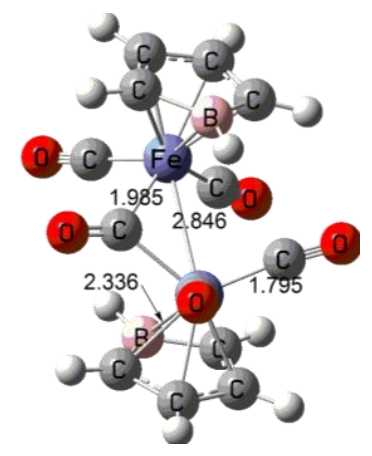

5S-4 $\left(C_{2}, 6.0\right)$

Figure 4. Optimized geometries for the $\left(\mathrm{C}_{4} \mathrm{H}_{4} \mathrm{BH}\right)_{2} \mathrm{Fe}_{2}(\mathrm{CO})_{5}$ structures. Bond distances are in $\AA$. 
Table 1. The $v(\mathrm{CO})$ vibrational frequencies $\left(\mathrm{cm}^{-1}\right)$ and the infrared intensities $(\mathrm{km} / \mathrm{mol})$ by the $\mathrm{BP} 86$ method for $\left(\mathrm{C}_{4} \mathrm{H}_{4} \mathrm{BH}\right)_{2} \mathrm{Fe}_{2}(\mathrm{CO})_{5}$ derivatives. Bridging $v(\mathrm{CO})$ frequencies are in bold.

\begin{tabular}{cccc}
\hline $\mathbf{5 S - 1}\left(\mathbf{C}_{\mathbf{2}}\right)$ & $\mathbf{5 S - 2}\left(\mathbf{C}_{\mathbf{1}}\right)$ & $\mathbf{5 S - 3}\left(\mathbf{C}_{\mathbf{1}}\right)$ & $\mathbf{5 S - 4}\left(\mathbf{C}_{\mathbf{2}}\right)$ \\
\hline $\mathbf{1 8 1 2}(\mathbf{3 4 4})$ & $\mathbf{1 8 0 7 ( 3 5 0 )}$ & $\mathbf{1 8 2 6}(\mathbf{3 1 4})$ & $\mathbf{1 8 2 8}(\mathbf{3 2 2})$ \\
$1967(18)$ & $1967(119)$ & $1948(306)$ & $1966(12)$ \\
$1981(765)$ & $1987(516)$ & $1984(400)$ & $1981(846)$ \\
$1994(1222)$ & $1995(595)$ & $2000(514)$ & $2001(1252)$ \\
$2018(99)$ & $2030(970)$ & $2030(993)$ & $2019(11)$ \\
\hline
\end{tabular}

3.1.2. $\left(\mathrm{C}_{4} \mathrm{H}_{4} \mathrm{BH}\right)_{2} \mathrm{Fe}_{2}(\mathrm{CO})_{4}$. The potential energy surface of $\left(\mathrm{C}_{4} \mathrm{H}_{4} \mathrm{BH}\right)_{2} \mathrm{Fe}_{2}(\mathrm{CO})_{4}$ is also fluxional, since no less than twelve different structures (including different conformers) have been obtained within $20 \mathrm{kcal} / \mathrm{mol}$. Six selected structures (Figure 5) are discussed here as representatives of the different structural types. All of these structures are found to be genuine minima with no imaginary vibrational frequencies.
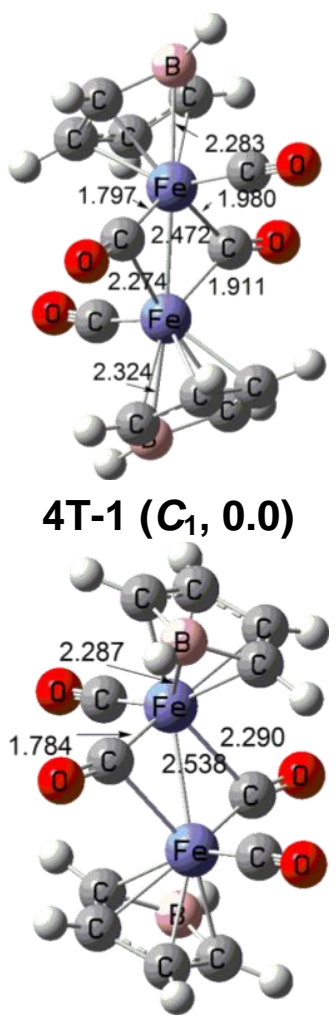

4S-1 $\left(C_{i}, 2.3\right)$
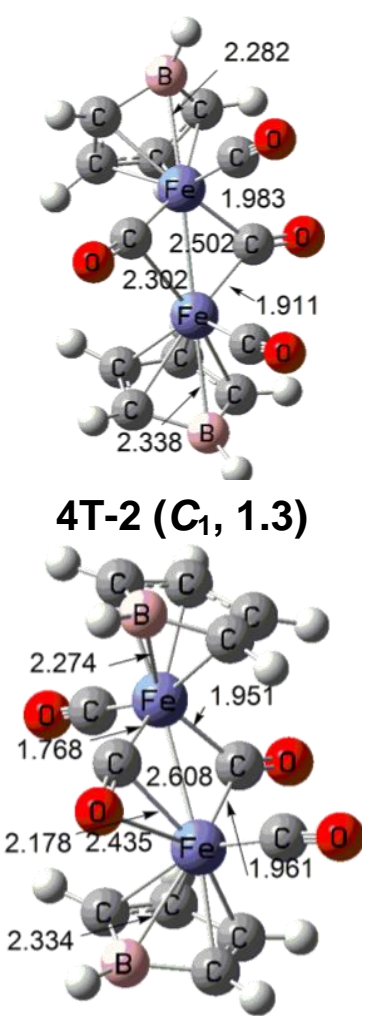

4S-2 $\left(C_{1}, 2.5\right)$
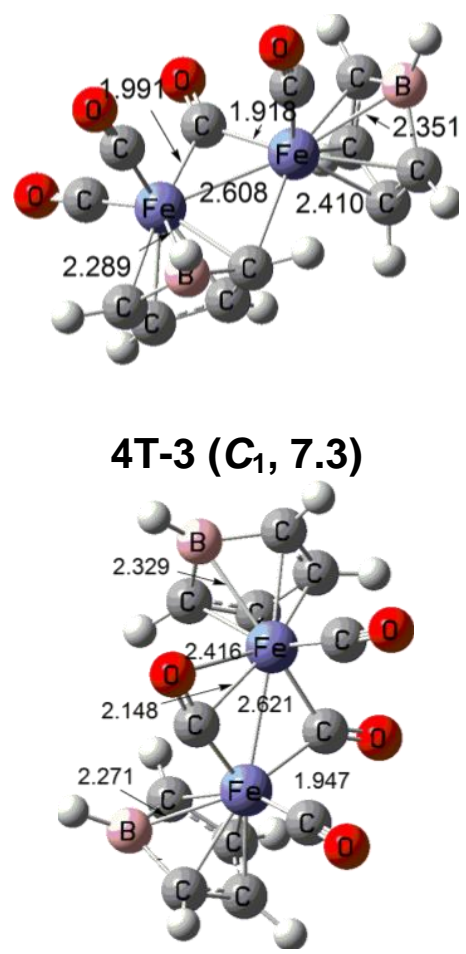

4S-3 $\left(C_{1}, 3.1\right)$

Figure 5. Optimized geometries for six representative $\left(\mathrm{C}_{4} \mathrm{H}_{4} \mathrm{BH}\right)_{2} \mathrm{Fe}_{2}(\mathrm{CO})_{4}$ structures. Bond distances are in $\AA$. 
The lowest energy $\left(\mathrm{C}_{4} \mathrm{H}_{4} \mathrm{BH}\right)_{2} \mathrm{Fe}_{2}(\mathrm{CO})_{4}$ structure 4T-1 has two bridging $\mathrm{CO}$ groups and two terminal $\mathrm{CO}$ groups in trans positions relative to the iron-iron bond, i.e., $\left(\mathrm{C}_{4} \mathrm{H}_{4} \mathrm{BH}\right)_{2} \mathrm{Fe}_{2}(\mathrm{CO})_{2}(\mu-\mathrm{CO})_{2}$ (Figure 5). The $\mathrm{Fe}=\mathrm{Fe}$ distance in 4T-1 of $2.472 \AA$ (B3LYP*) suggests the formal double bond required to give each iron atom the favored 18-electron configuration. The two unpaired electrons of the triplet spin state reside in two $\pi$ orthogonal "half-bond" components of the formal $\sigma+2 / 2 \pi$ double bond. A similar $\sigma+2 / 2 \pi \mathrm{Fe}=\mathrm{Fe}$ double bond is found in the stable triplet spin state cyclopentadienyliron carbonyl derivatives $\left(\eta^{5}-\mathrm{R}_{5} \mathrm{C}_{5}\right)_{2} \mathrm{Fe}_{2}(\mu-\mathrm{CO})_{3}\left(\mathrm{R}=\mathrm{H}, \mathrm{CH}_{3}\right)$, which have been synthesized and structurally characterized by X-ray crystallography [49, 50, 51]. A similar triplet doubly bridged structure 4T-2, with the two terminal CO groups in cis positions, lies only $\sim 1.3 \mathrm{kcal} / \mathrm{mol}$ above 4T-1 (Figure 5). The Fe=Fe distances of $2.502 \AA$ (B3LYP*) in 4T-2 are almost identical to those in 4T-1 suggesting a similar type of $\sigma+2 / 2 \pi$ double bond with the two unpaired electrons of the triplet spin state in the two $\pi$ "half-bonds."

The triplet $\left(\mathrm{C}_{4} \mathrm{H}_{4} \mathrm{BH}\right)_{2} \mathrm{Fe}_{2}(\mathrm{CO})_{4}$ structure 4T-3, lying $7.3 \mathrm{kcal} / \mathrm{mol}$ (B3LYP*) above 4T-1, has one bridging $\mathrm{CO}$ group and three terminal $\mathrm{CO}$ groups (Figure 5). The $\mathrm{Fe}-\mathrm{Fe}$ distance of $2.607 \AA$ (B3LYP*) in $\mathbf{4 T - 3}$ corresponds to a formal single bond, thereby giving each iron atom a 17-electron configuration corresponding to a binuclear triplet.

The lowest energy singlet $\left(\mathrm{C}_{4} \mathrm{H}_{4} \mathrm{BH}\right)_{2} \mathrm{Fe}_{2}(\mathrm{CO})_{4}$ structure $4 \mathrm{~S}-\mathbf{1}\left(C_{i}\right)$ is a trans doubly bridged structure lying $2.3 \mathrm{kcal} / \mathrm{mol}(\mathrm{B} 3 \mathrm{LYP} *)$ above the triplet global minimum (Figure 5). The iron-iron distance of $2.538 \AA$ (B3LYP*) in $\mathbf{4 S - 1}$ can be interpreted as the formal $\mathrm{Fe}=\mathrm{Fe}$ double bond required to give each $\mathrm{Fe}$ atom the favored 18-electron configuration.

The singlet $\left(\mathrm{C}_{4} \mathrm{H}_{4} \mathrm{BH}\right)_{2} \mathrm{Fe}_{2}(\mathrm{CO})_{4}$ structures $\mathbf{4 S - 2}$ and $\mathbf{4 S - 3}$ are a pair of trans/cis doubly bridged isomers with similar geometries and predicted to have energies within $\sim 1 \mathrm{kcal} / \mathrm{mol}$ of the lowest energy singlet $4 \mathrm{~S}-1$ (Figure 5). In both $4 \mathrm{~S}-2$ and $4 \mathrm{~S}-3$, one of the bridging $\mathrm{CO}$ groups has a relatively short Fe-O distance of $\sim 2.4 \AA$, suggesting a fourelectron donor bridging $\eta^{2}-\mu-\mathrm{CO}$ group. The second bridging $\mathrm{CO}$ group in either $\mathbf{4 S - 2}$ or 4S-3 is a normal two-electron donor. The predicted $\mathrm{Fe}-\mathrm{Fe}$ distances of $2.608 \AA$ (B3LYP*) in 4S-2 and 2.621 $\AA$ (B3LYP*) in 4S-3 correspond to formal single bonds, thereby giving each iron atom the favored 18-electron configuration in these structures with a four-electron donor $\eta^{2}-\mu-\mathrm{CO}$ group.

Similar to $\left(\mathrm{C}_{4} \mathrm{H}_{4} \mathrm{BH}\right)_{2} \mathrm{Fe}_{2}(\mathrm{CO})_{5}$ structures, the $v(\mathrm{CO})$ frequencies for the bridging $\mathrm{CO}$ groups in $\left(\mathrm{C}_{4} \mathrm{H}_{4} \mathrm{BH}\right)_{2} \mathrm{Fe}_{2}(\mathrm{CO})_{4}$ fall in the fairly typical range from 1831 to $1891 \mathrm{~cm}^{-1}$ (Table 2), which is $\sim 120 \mathrm{~cm}^{-1}$ below the $v(\mathrm{CO})$ frequencies (1969 to $2005 \mathrm{~cm}^{-1}$ ) for the terminal $\mathrm{CO}$ groups in accord with expectation. 
Table 2. The $v(\mathrm{CO})$ frequencies by the $\mathrm{BP} 86$ method for $\left(\mathrm{C}_{4} \mathrm{H}_{4} \mathrm{BH}\right)_{2} \mathrm{Fe}_{2}(\mathrm{CO})_{4}$ derivatives. Bridging $v(\mathrm{CO})$ frequencies are in bold.

\begin{tabular}{ccccc}
\hline 4T-1 & 4S-1 & 4T-2 & 4S-2 & 4S-3 \\
\hline $\mathbf{1 8 4 6 ( 7 8 8 )}$ & $\mathbf{1 8 8 4 ( 0 )}$ & $\mathbf{1 8 3 4 ( 7 7 1 )}$ & $\mathbf{1 8 3 1 ( 5 0 4 )}$ & $\mathbf{1 8 3 1 ( 5 9 5 )}$ \\
$\mathbf{1 8 4 8}(\mathbf{0})$ & $\mathbf{1 8 9 1 ( 6 5 7 )}$ & $\mathbf{1 8 3 5}(\mathbf{2 3})$ & $\mathbf{1 8 4 2 ( 1 1 9 )}$ & $\mathbf{1 8 3 9 ( 3 4 )}$ \\
$1972(1230)$ & $1973(1278)$ & $1969(183)$ & $1974(1075)$ & $1975(224)$ \\
$1985(0)$ & $1986(0)$ & $2005(1065)$ & $1987(160)$ & $2005(1137)$ \\
\hline
\end{tabular}

3.1.3 $\left(\mathrm{C}_{4} \mathrm{H}_{4} \mathrm{BH}\right)_{2} \mathrm{Fe}_{2}(\mathrm{CO})_{3}$. Four low-energy $\left(\mathrm{C}_{4} \mathrm{H}_{4} \mathrm{BH}\right)_{2} \mathrm{Fe}_{2}(\mathrm{CO})_{3}$ structures have been found, including structures with one, two, or three bridging $\mathrm{CO}$ groups (Figure 6). All of these structures are genuine minima. Since the B3LYP* method found significant spin contamination for the triplet structures $\left(\left\langle\mathrm{S}^{2}\right\rangle=2.55\right.$ or 2.44 versus the ideal 2.00), a quintet spin state $\left(\mathrm{C}_{4} \mathrm{H}_{4} \mathrm{BH}\right)_{2} \mathrm{Fe}_{2}(\mathrm{CO})_{3}$ structure was also explored. However, the energy of this quintet structure was so high $(\sim 30 \mathrm{kcal} / \mathrm{mol})$ that it is not discussed in this paper.
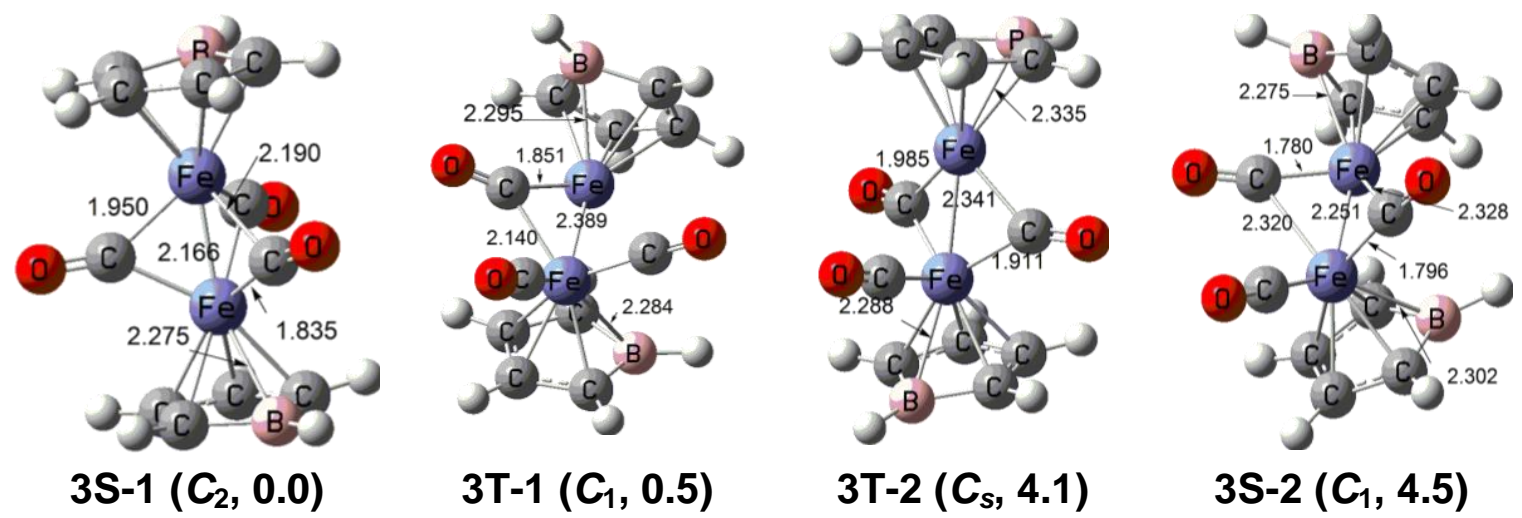

Figure 6. Optimized geometries for the $\left(\mathrm{C}_{4} \mathrm{H}_{4} \mathrm{BH}\right)_{2} \mathrm{Fe}_{2}(\mathrm{CO})_{3}$ structures. Bond distances are in $\AA$.

The lowest energy $\left(\mathrm{C}_{4} \mathrm{H}_{4} \mathrm{BH}\right)_{2} \mathrm{Fe}_{2}(\mathrm{CO})_{3}$ structure is 3S-1 (B3LYP*) with three bridging $\mathrm{CO}$ groups (Figure 6). The short Fe $\equiv$ Fe distance in 3S-1 of $2.166 \AA$ (B3LYP*) is consistent with a formal triple bond, thereby giving each iron atom the favored 18-electron configuration. Structure 3T-1, lying only $0.5 \mathrm{kcal} / \mathrm{mol}$ in energy above 3S-1, has one bridging $\mathrm{CO}$ group. The Fe=Fe distance in 3T-1 of $2.389 \AA$ (B3LYP*) is $\sim 0.2 \AA$ longer than the $\mathrm{Fe} \equiv \mathrm{Fe}$ distance in $\mathbf{3 S - 1}$ and thus suggests a $\mathrm{Fe}=\mathrm{Fe}$ double bond. This gives each iron atom in 3T-1 a 17-electron configuration, consistent with a binuclear triplet.

Two doubly bridged $\left(\mathrm{C}_{4} \mathrm{H}_{4} \mathrm{BH}\right)_{2} \mathrm{Fe}_{2}(\mathrm{CO})(\mu-\mathrm{CO})_{2}$ structures were found, namely the triplet trans structure 3T-2 $\left(C_{s}\right)$ and the singlet cis structure 3S-2 $\left(C_{1}\right)$, lying 4.1 and 
$4.5 \mathrm{kcal} / \mathrm{mol}$, respectively, in energy above 3S-1 (Figure 6). The Fe=Fe distance in 3T-2 of $2.341 \AA$ (B3LYP*) can correspond to a formal double bond, thereby giving each iron atom a 17-electron configuration, corresponding to a binuclear triplet. The $\mathrm{Fe} \equiv \mathrm{Fe}$ distance in the singlet 3S-2 of $2.251 \AA$ (B3LYP*) is $\sim 0.1 \AA$ shorter than that in triplet 3T-2. This suggests a formal $\mathrm{Fe} \equiv \mathrm{Fe}$ triple bond in 3S-2 thereby giving each iron atom the favored 18-electron configuration. Because of the asymmetry of the $\mathrm{CO}$ distribution in 3S-2 this $\mathrm{Fe} \equiv \mathrm{Fe}$ triple bond is polarized with four of the six electrons from the iron atom bearing the terminal CO group (the "bottom" iron in Figure 6) and the other two electrons from the iron atom bonded only to the two bridging CO groups (the "top" iron in Figure $6)$.

Similar to $\left(\mathrm{C}_{4} \mathrm{H}_{4} \mathrm{BH}\right)_{2} \mathrm{Fe}_{2}(\mathrm{CO})_{5}$ and $\left(\mathrm{C}_{4} \mathrm{H}_{4} \mathrm{BH}\right)_{2} \mathrm{Fe}_{2}(\mathrm{CO})_{4}$, the $v(\mathrm{CO})$ frequencies of the bridging $\mathrm{CO}$ groups range from 1839 to $1912 \mathrm{~cm}^{-1}$ (Table 3), while the terminal $v(\mathrm{CO})$ frequencies range from 1962 to $2005 \mathrm{~cm}^{-1}$.

Table 3. The $v(\mathrm{CO})$ frequencies by the BP86 method for $\left(\mathrm{C}_{4} \mathrm{H}_{4} \mathrm{BH}\right)_{2} \mathrm{Fe}_{2}(\mathrm{CO})_{3}$ derivatives. Bridging $v(\mathrm{CO})$ frequencies are in bold.

\begin{tabular}{cccc}
\hline 3S-1 & 3T-1 & 3T-2 & 3S-2 \\
\hline $\mathbf{1 8 7 9}(\mathbf{7 2 9})$ & $\mathbf{1 8 7 5}(\mathbf{3 6 6})$ & $\mathbf{1 8 3 9}(\mathbf{8 4 0})$ & $\mathbf{1 9 0 0}(\mathbf{7 1 0})$ \\
$\mathbf{1 8 8 4}(\mathbf{7 3 5})$ & $1962(482)$ & $\mathbf{1 8 5 2}(\mathbf{1 1 1})$ & $\mathbf{1 9 1 0}(\mathbf{1 1 0})$ \\
$\mathbf{1 9 1 2}(\mathbf{1 1})$ & $2005(919)$ & $1976(540)$ & $1989(1010)$ \\
\hline
\end{tabular}

3.1.4. $\left(\mathrm{C}_{4} \mathrm{H}_{4} \mathrm{BH}\right)_{2} \mathrm{Fe}_{2}(\mathrm{CO})_{2}$. Three low-energy $\left(\mathrm{C}_{4} \mathrm{H}_{4} \mathrm{BH}\right)_{2} \mathrm{Fe}_{2}(\mathrm{CO})_{2}$ structures were found (Figure 7). All three structures are predicted to be genuine minima with no imaginary vibrational frequencies. Singlet structures are not discussed here, since they lie at least $40 \mathrm{kcal} / \mathrm{mol}$ higher in energy than the global minimum.

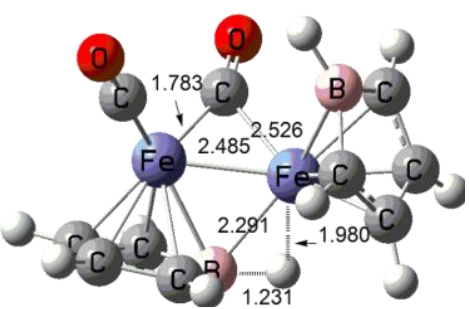

2Q-1 $\left(C_{1}, 0.0\right)$

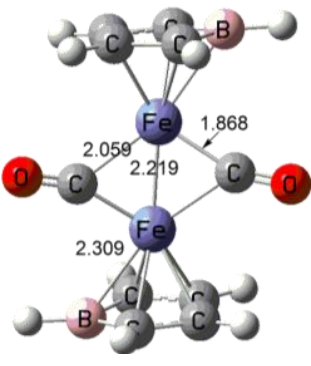

2T-1 $\left(C_{2}, 15.0\right)$

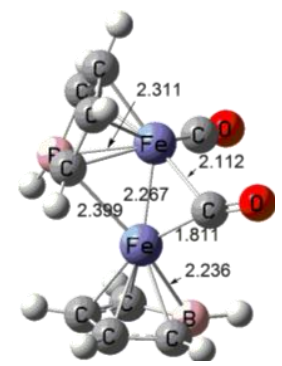

2T-2 $\left(C_{1}, 15.4\right)$

Figure 7. Optimized geometries for the $\left(\mathrm{C}_{4} \mathrm{H}_{4} \mathrm{BH}\right)_{2} \mathrm{Fe}_{2}(\mathrm{CO})_{2}$ structures. Bond distances are in $\AA$. 
The lowest-energy $\left(\mathrm{C}_{4} \mathrm{H}_{4} \mathrm{BH}\right)_{2} \mathrm{Fe}_{2}(\mathrm{CO})_{2}$ structure is the quintet singly-bridged structure 2Q-1, in which a boron atom bridges both iron atoms (Figure 7). In 2Q-1 the long B-H distance $1.231 \AA$ (B3LYP*) leads to an unusually low $v(\mathrm{BH})$ frequency of $2237 \mathrm{~cm}^{-1}$ (BP86). This hydrogen atom is also within bonding distance of the iron atom with a short $\mathrm{Fe}-\mathrm{H}$ distance of $1.980 \AA$ (B3LYP*). Thus this hydrogen atom bridges an $\mathrm{Fe}-\mathrm{B}$ bond to form a three-center two-electron (3c-2e) B-H-Fe bond. The Fe=Fe distance in 2Q-1 of $2.485 \AA$ (B3LYP*) suggests a formal $\mathrm{Fe}=\mathrm{Fe}$ double bond to give one iron atom a 17-electron configuration and the other iron atom a 15-eletron configuration, consistent with a binuclear quintet with four unpaired electrons.

The two triplet $\left(\mathrm{C}_{4} \mathrm{H}_{4} \mathrm{BH}\right)_{2} \mathrm{Fe}_{2}(\mathrm{CO})_{2}$ structures, i.e., doubly-bridged $\mathbf{2 T - 1}\left(C_{2}\right)$, and singly-bridged 2T-2 $\left(C_{1}\right)$, have similar energies, lying $\sim 15 \mathrm{kcal} / \mathrm{mol}$ above 2Q-1. The $\mathrm{Fe} \equiv \mathrm{Fe}$ distances of $2.219 \AA$ (B3LYP*) in 2T-1 and $2.267 \AA$ (B3LYP*) in 2T-2 suggest formal triple bonds to give the metal atoms 17-electron configurations for the binuclear triplet state. The $v(\mathrm{CO})$ frequencies for the bridging $\mathrm{CO}$ groups in $\left(\mathrm{C}_{4} \mathrm{H}_{4} \mathrm{BH}\right)_{2} \mathrm{Fe}_{2}(\mathrm{CO})_{2}$ fall in the fairly typical range of 1851 to $1869 \mathrm{~cm}^{-1}$, while the terminal $v(\mathrm{CO})$ frequencies are significantly higher in the narrow range from 1973 to $1977 \mathrm{~cm}^{-1}$ (Table 4).

Table 4. The $v(\mathrm{CO})$ frequencies by the $\mathrm{BP} 86$ method for $\left(\mathrm{C}_{4} \mathrm{H}_{4} \mathrm{BH}\right)_{2} \mathrm{Fe}_{2}(\mathrm{CO})_{2}$ derivatives. Bridging $v(\mathrm{CO})$ frequencies are in bold.

\begin{tabular}{ccc}
\hline 2Q-1 & 2T-1 & 2T-2 \\
\hline $\mathbf{1 8 5 1}(570)$ & $\mathbf{1 8 5 9}(846)$ & $\mathbf{1 8 6 2}(477)$ \\
$1977(912)$ & $\mathbf{1 8 6 9}(63)$ & $1973(958)$ \\
\hline
\end{tabular}

3.1.5. $\left(\mathrm{C}_{4} \mathrm{H}_{4} \mathrm{BH}\right)_{2} \mathrm{Fe}_{2}(\mathrm{CO})$. Singlet, triplet, and quintet $\left(\mathrm{C}_{4} \mathrm{H}_{4} \mathrm{BH}\right)_{2} \mathrm{Fe}_{2}(\mathrm{CO})$ structures were found. However, the singlet structures were found to lie at least $40 \mathrm{kcal} / \mathrm{mol}$ above the global minimum so they are not discussed in this paper. In the two lowest energy structures 1Q-1 and 1T-1, the single $\mathrm{CO}$ group bridges the central $\mathrm{Fe}_{2}$ unit, i.e., $\left(\mathrm{C}_{4} \mathrm{H}_{4} \mathrm{BH}\right)_{2} \mathrm{Fe}_{2}(\mu-\mathrm{CO})$ (Figure 8). The iron-iron distances in these two $\left(\mathrm{C}_{4} \mathrm{H}_{4} \mathrm{BH}\right)_{2} \mathrm{Fe}_{2}(\mu-\mathrm{CO})$ structures fall in a fairly narrow range from $2.382 \AA$ to $2.422 \AA$ despite the different spin states.

The $\left(\mathrm{C}_{4} \mathrm{H}_{4} \mathrm{BH}\right)_{2} \mathrm{Fe}_{2}(\mathrm{CO})$ structure 1Q-1 is the global minimum, while 1T-1 lies $7.3 \mathrm{kcal} / \mathrm{mol}$ (B3LYP*) above 1Q-1 (Figure 8). Both 1Q-1 and 1T-1 exhibit some interesting features. Thus, in both structures the planes of the two $\eta^{4}-\mathrm{C}_{4} \mathrm{H}_{4} \mathrm{~B}$ rings planes are nearly perpendicular to each other. As a result, the boron atom in one of the $\mathrm{C}_{4} \mathrm{H}_{4} \mathrm{BH}$ rings bridges the two iron atoms as indicated by the short Fe-B distances of 2.263 and $2.313 \AA$ (B3LYP*) in 1Q-1 and 1T-1, respectively, involving this boron atom. In 
addition, there are short Fe-H distances of 1.884 and $1.790 \AA$ (B3LYP*) in 1Q-1 and 1T-1, respectively. These short Fe-H distances are accompanied by relatively long B-H distances of 1.243 and 1.242 $\AA$ (B3LYP*) for 1Q-1 and 1T-1, respectively, which are $\sim 0.05 \AA$ longer than normal B-H single bond distances. This leads to unusually low $v(\mathrm{BH})$ vibrational frequencies $\left(2135 \mathrm{~cm}^{-1}\right.$ and $2188 \mathrm{~cm}^{-1}$ by BP86) by $\sim 400 \mathrm{~cm}^{-1}$ relative to typical values. This agostic hydrogen atom thus bridges the boron atom and the iron atom leading to a $3 \mathrm{c}-2 \mathrm{e} \mathrm{B}-\mathrm{H}-\mathrm{Fe}$ bond.
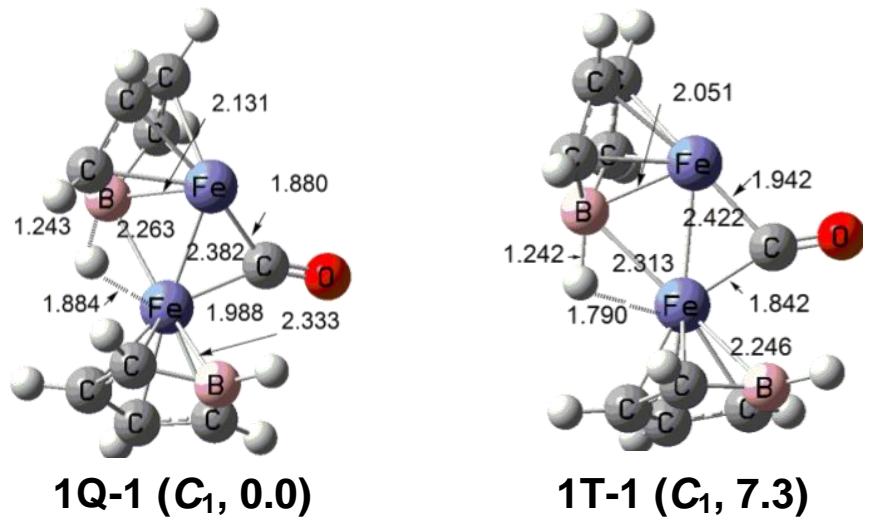

Figure 8. Optimized geometries for the two $\left(\mathrm{C}_{4} \mathrm{H}_{4} \mathrm{BH}\right)_{2} \mathrm{Fe}_{2}(\mathrm{CO})$ structures. Bond distances are in $\AA$.

Table 5. Bond distances in $\AA$ (B3LYP*) and the $v(\mathrm{BH})$ frequencies in $\mathrm{cm}^{-1}$ (BP86) for the agostic hydrogen atoms in the $\left(\mathrm{C}_{4} \mathrm{H}_{4} \mathrm{BH}\right)_{2} \mathrm{Fe}_{2}(\mathrm{CO})$ structures.

\begin{tabular}{cccc}
\hline & $\mathrm{r}(\mathrm{Fe}-\mathrm{H})$ & $\mathrm{r}(\mathrm{B}-\mathrm{H})$ & $v(\mathrm{BH})$ \\
\hline $\mathbf{1 Q}-1$ & 1.884 & 1.243 & 2135 \\
$\mathbf{1 T}-\mathbf{1}$ & 1.790 & 1.242 & 2188 \\
\hline
\end{tabular}

\subsection{Thermochemistry}

Table 6 reports the dissociation energies for loss of a single carbonyl in the lowest energy $\left(\mathrm{C}_{4} \mathrm{H}_{4} \mathrm{BH}\right)_{2} \mathrm{Fe}_{2}(\mathrm{CO})_{n}$ structures, namely the following process:

$$
\left(\mathrm{C}_{4} \mathrm{H}_{4} \mathrm{BH}\right)_{2} \mathrm{Fe}_{2}(\mathrm{CO})_{n} \rightarrow\left(\mathrm{C}_{4} \mathrm{H}_{4} \mathrm{BH}\right)_{2} \mathrm{Fe}_{2}(\mathrm{CO})_{n-1}+\mathrm{CO} \text {. }
$$

In determining these dissociation energies, the fragments were allowed to relax.

The sequence of the predicted energies for the four stages of successive dissociation of $\mathrm{CO}$ groups from $\left(\mathrm{C}_{4} \mathrm{H}_{4} \mathrm{BH}\right)_{2} \mathrm{Fe}_{2}(\mathrm{CO})_{5}$ leading ultimately to $\left(\mathrm{C}_{4} \mathrm{H}_{4} \mathrm{BH}\right)_{2} \mathrm{Fe}_{2}(\mathrm{CO})$ is $32.8,28.7,29.4$, and $46.4 \mathrm{kcal} / \mathrm{mol}$. These values are similar to 
the experimental bond dissociation energies for the simple metal carbonyls $\mathrm{Ni}(\mathrm{CO})_{4}$, $\mathrm{Fe}(\mathrm{CO})_{5}$, and $\mathrm{Cr}(\mathrm{CO})_{6}$ of $27 \mathrm{kcal} / \mathrm{mol}, 41 \mathrm{kcal} / \mathrm{mol}$, and $37 \mathrm{kcal} / \mathrm{mol}$, respectively [52].

The CO dissociation energies for the previously studied related binuclear borole iron carbonyl systems $\left(\mathrm{C}_{4} \mathrm{H}_{4} \mathrm{BCH}_{3}\right)_{2} \mathrm{Fe}_{2}(\mathrm{CO})_{n}$ [25] and $\left[\mathrm{C}_{4} \mathrm{H}_{4} \mathrm{BN}\left(\mathrm{CH}_{3}\right)_{2}\right]_{2} \mathrm{Fe}_{2}(\mathrm{CO})_{n}$ [26] were reported using the B3LYP and BP86 methods. However, as discussed above, the B3LYP* method is expected to predict more reliable relative energies for the different electronic spin states [38, 39, 40]. For a valid comparison between the three $\left(\mathrm{C}_{4} \mathrm{H}_{4} \mathrm{BR}\right)_{2} \mathrm{Fe}_{2}(\mathrm{CO})_{n}$ systems $\left[\mathrm{R}=\mathrm{CH}_{3},\left(\mathrm{CH}_{3}\right)_{2} \mathrm{~N}\right.$, and $\left.\mathrm{H}\right]$, we re-optimized the lowest energy structures for the $\left(\mathrm{C}_{4} \mathrm{H}_{4} \mathrm{BCH}_{3}\right)_{2} \mathrm{Fe}_{2}(\mathrm{CO})_{n}$ and $\left[\mathrm{C}_{4} \mathrm{H}_{4} \mathrm{BN}\left(\mathrm{CH}_{3}\right)_{2}\right]_{2} \mathrm{Fe}_{2}(\mathrm{CO})_{n}$ systems. The $\mathrm{CO}$ dissociation energies based on these B3LYP* structures are also listed in Table 6. The CO dissociation energies all of the structures are seen to be substantial and similar to the experimental results for $\mathrm{Ni}(\mathrm{CO})_{4}, \mathrm{Fe}(\mathrm{CO})_{5}$, and $\mathrm{Cr}(\mathrm{CO})_{6}[52]$.

Table 6. Dissociation energies $(\mathrm{kcal} / \mathrm{mol})$ for the successive removal of carbonyl groups for $\left(\mathrm{C}_{4} \mathrm{H}_{4} \mathrm{BH}\right)_{2} \mathrm{Fe}_{2}(\mathrm{CO})_{n}$ predicted by the $\mathrm{B} 3 \mathrm{LYP} *$ method. Those for $\left(\mathrm{C}_{4} \mathrm{H}_{4} \mathrm{BCH}_{3}\right)_{2} \mathrm{Fe}_{2}(\mathrm{CO})_{\mathrm{n}}$ and $\left[\mathrm{C}_{4} \mathrm{H}_{4} \mathrm{BN}\left(\mathrm{CH}_{3}\right)_{2}\right]_{2} \mathrm{Fe}_{2}(\mathrm{CO})_{\mathrm{n}}$ are also listed for comparison.

\begin{tabular}{rc}
\hline & B3LYP* \\
\hline$\left(\mathrm{C}_{4} \mathrm{H}_{4} \mathrm{BH}\right)_{2} \mathrm{Fe}_{2}(\mathrm{CO})_{5}(\mathbf{5 S}-\mathbf{1}) \rightarrow\left(\mathrm{C}_{4} \mathrm{H}_{4} \mathrm{BH}\right)_{2} \mathrm{Fe}_{2}(\mathrm{CO})_{4}+\mathrm{CO}$ & 32.8 \\
$\left(\mathrm{C}_{4} \mathrm{H}_{4} \mathrm{BH}\right)_{2} \mathrm{Fe}_{2}(\mathrm{CO})_{4}(\mathbf{4 T - 1}) \rightarrow\left(\mathrm{C}_{4} \mathrm{H}_{4} \mathrm{BH}\right)_{2} \mathrm{Fe}_{2}(\mathrm{CO})_{3}+\mathrm{CO}$ & 28.7 \\
$\left(\mathrm{C}_{4} \mathrm{H}_{4} \mathrm{BH}\right)_{2} \mathrm{Fe}_{2}(\mathrm{CO})_{3}(\mathbf{3 S}-\mathbf{1}) \rightarrow\left(\mathrm{C}_{4} \mathrm{H}_{4} \mathrm{BH}\right)_{2} \mathrm{Fe}_{2}(\mathrm{CO})_{2}+\mathrm{CO}$ & 29.4 \\
$\left(\mathrm{C}_{4} \mathrm{H}_{4} \mathrm{BH}\right)_{2} \mathrm{Fe}_{2}(\mathrm{CO})_{2}(\mathbf{2 Q - 1}) \rightarrow\left(\mathrm{C}_{4} \mathrm{H}_{4} \mathrm{BH}\right)_{2} \mathrm{Fe}_{2}(\mathrm{CO})(\mathbf{1 Q}-\mathbf{1})+\mathrm{CO}$ & 46.4 \\
& \\
& \\
$\left(\mathrm{C}_{4} \mathrm{H}_{4} \mathrm{BCH}_{3}\right)_{2} \mathrm{Fe}_{2}(\mathrm{CO})_{5} \rightarrow\left(\mathrm{C}_{4} \mathrm{H}_{4} \mathrm{BCH}_{3}\right)_{2} \mathrm{Fe}_{2}(\mathrm{CO})_{4}+\mathrm{CO}$ & 28.8 \\
$\left(\mathrm{C}_{4} \mathrm{H}_{4} \mathrm{BCH}_{3}\right)_{2} \mathrm{Fe}_{2}(\mathrm{CO})_{4} \rightarrow\left(\mathrm{C}_{4} \mathrm{H}_{4} \mathrm{BCH}_{3}\right)_{2} \mathrm{Fe}_{2}(\mathrm{CO})_{3}+\mathrm{CO}$ & 27.0 \\
$\left(\mathrm{C}_{4} \mathrm{H}_{4} \mathrm{BCH}_{3}\right)_{2} \mathrm{Fe}_{2}(\mathrm{CO})_{3} \rightarrow\left(\mathrm{C}_{4} \mathrm{H}_{4} \mathrm{BCH}_{3}\right)_{2} \mathrm{Fe}_{2}(\mathrm{CO})_{2}+\mathrm{CO}$ & 43.4 \\
$\left.\left(\mathrm{C}_{4} \mathrm{H}_{4} \mathrm{BCH}\right)_{3}\right)_{2} \mathrm{Fe}_{2}(\mathrm{CO})_{2} \rightarrow\left(\mathrm{C}_{4} \mathrm{H}_{4} \mathrm{BCH}\right)_{2} \mathrm{Fe}_{2}(\mathrm{CO})+\mathrm{CO}$ & 31.8 \\
& \\
{$\left[\mathrm{C}_{4} \mathrm{H}_{4} \mathrm{BN}\left(\mathrm{CH}_{3}\right)_{2}\right]_{2} \mathrm{Fe}_{2}(\mathrm{CO})_{5} \rightarrow\left[\mathrm{C}_{4} \mathrm{H}_{4} \mathrm{BN}\left(\mathrm{CH}_{3}\right)_{2}\right]_{2} \mathrm{Fe}_{2}(\mathrm{CO})_{4}+\mathrm{CO}$} & 30.7 \\
{$\left[\mathrm{C}_{4} \mathrm{H}_{4} \mathrm{BN}\left(\mathrm{CH}_{3}\right)_{2}\right]_{2} \mathrm{Fe}_{2}(\mathrm{CO})_{4} \rightarrow\left[\mathrm{C}_{4} \mathrm{H}_{4} \mathrm{BN}\left(\mathrm{CH}_{3}\right)_{2}\right]_{2} \mathrm{Fe}_{2}(\mathrm{CO})_{3}+\mathrm{CO}$} & 26.4 \\
{$\left[\mathrm{C}_{4} \mathrm{H}_{4} \mathrm{BN}\left(\mathrm{CH}_{3}\right)_{2}\right]_{2} \mathrm{Fe}_{2}(\mathrm{CO})_{3} \rightarrow\left[\mathrm{C}_{4} \mathrm{H}_{4} \mathrm{BN}\left(\mathrm{CH}_{3}\right)_{2}\right]_{2} \mathrm{Fe}_{2}(\mathrm{CO})_{2}+\mathrm{CO}$} & 36.4 \\
{$\left[\mathrm{C}_{4} \mathrm{H}_{4} \mathrm{BN}\left(\mathrm{CH}_{3}\right)_{2}\right]_{2} \mathrm{Fe}_{2}(\mathrm{CO})_{2} \rightarrow\left[\mathrm{C}_{4} \mathrm{H}_{4} \mathrm{BN}\left(\mathrm{CH}_{3}\right)_{2}\right]_{2} \mathrm{Fe}_{2}(\mathrm{CO})+\mathrm{CO}$} & 30.9 \\
\hline
\end{tabular}

In order to compare the relative stabilities for the $\left(\mathrm{C}_{4} \mathrm{H}_{4} \mathrm{BR}\right)_{2} \mathrm{Fe}_{2}(\mathrm{CO})_{n}$ structures $\left[\mathrm{R}=\mathrm{CH}_{3},\left(\mathrm{CH}_{3}\right)_{2} \mathrm{~N}\right.$, and $\left.\mathrm{H}\right]$ having different numbers of $\mathrm{CO}$ groups, we determined the energies for the following disproportionation reactions using the lowest energy structures (Table 7):

$$
2\left(\mathrm{C}_{4} \mathrm{H}_{4} \mathrm{BH}\right)_{2} \mathrm{Fe}_{2}(\mathrm{CO})_{n} \rightarrow\left(\mathrm{C}_{4} \mathrm{H}_{4} \mathrm{BH}\right)_{2} \mathrm{Fe}_{2}(\mathrm{CO})_{n+1}+\left(\mathrm{C}_{4} \mathrm{H}_{4} \mathrm{BH}\right)_{2} \mathrm{Fe}_{2}(\mathrm{CO})_{n-1}
$$


The $\left(\mathrm{C}_{4} \mathrm{H}_{4} \mathrm{BH}\right)_{2} \mathrm{Fe}_{2}(\mathrm{CO})_{3}$ structure is seen to be only marginally stable towards disproportionation whereas $\left(\mathrm{C}_{4} \mathrm{H}_{4} \mathrm{BH}\right)_{2} \mathrm{Fe}_{2}(\mathrm{CO})_{2}$ appears to be stable towards disproportionation. This contrasts with the $\left(\mathrm{C}_{4} \mathrm{H}_{4} \mathrm{BCH}_{3}\right)_{2} \mathrm{Fe}_{2}(\mathrm{CO})_{n}$ and $\left[\mathrm{C}_{4} \mathrm{H}_{4} \mathrm{BN}\left(\mathrm{CH}_{3}\right)_{2}\right]_{2} \mathrm{Fe}_{2}(\mathrm{CO})_{n}$ systems for which the tricarbonyls are viable with respect to disproportionation, whereas the dicarbonyls and tetracarbonyls are disfavored relative to disproportionation. This difference may relate to the stabilization of the lowest energy dicarbonyl $\left(\mathrm{C}_{4} \mathrm{H}_{4} \mathrm{BH}\right)_{2} \mathrm{Fe}_{2}(\mathrm{CO})_{2}$ structure 2Q-1 by formation of the $3 \mathrm{c}-2 \mathrm{e} \mathrm{B}-\mathrm{H}-\mathrm{Fe}$ bond.

Table 7. Energies (kcal/mol) for the disproportionation reaction $2\left(\mathrm{C}_{4} \mathrm{H}_{4} \mathrm{BH}\right)_{2} \mathrm{Fe}_{2}(\mathrm{CO})_{n} \rightarrow$ $\left(\mathrm{C}_{4} \mathrm{H}_{4} \mathrm{BH}\right)_{2} \mathrm{Fe}_{2}(\mathrm{CO})_{n+1}+\left(\mathrm{C}_{4} \mathrm{H}_{4} \mathrm{BH}\right)_{2} \mathrm{Fe}_{2}(\mathrm{CO})_{n-1}$ predicted by the B3LYP* method. Those for $\left(\mathrm{C}_{4} \mathrm{H}_{4} \mathrm{BCH}_{3}\right)_{2} \mathrm{Fe}_{2}(\mathrm{CO})_{\mathrm{n}}$ and $\left[\mathrm{C}_{4} \mathrm{H}_{4} \mathrm{BN}\left(\mathrm{CH}_{3}\right)_{2}\right]_{2} \mathrm{Fe}_{2}(\mathrm{CO})_{\mathrm{n}}$ are also listed for comparison.

\begin{tabular}{cc}
\hline & $\mathrm{B} 3 \mathrm{LYP} *$ \\
\hline $2\left(\mathrm{C}_{4} \mathrm{H}_{4} \mathrm{BH}\right)_{2} \mathrm{Fe}_{2}(\mathrm{CO})_{4} \rightarrow\left(\mathrm{C}_{4} \mathrm{H}_{4} \mathrm{BH}\right)_{2} \mathrm{Fe}_{2}(\mathrm{CO})_{5}+\left(\mathrm{C}_{4} \mathrm{H}_{4} \mathrm{BH}\right)_{2} \mathrm{Fe}_{2}(\mathrm{CO})_{3}$ & -4.1 \\
$2\left(\mathrm{C}_{4} \mathrm{H}_{4} \mathrm{BH}\right)_{2} \mathrm{Fe}_{2}(\mathrm{CO})_{3} \rightarrow\left(\mathrm{C}_{4} \mathrm{H}_{4} \mathrm{BH}\right)_{2} \mathrm{Fe}_{2}(\mathrm{CO})_{4}+\left(\mathrm{C}_{4} \mathrm{H}_{4} \mathrm{BH}\right)_{2} \mathrm{Fe}_{2}(\mathrm{CO})_{2}$ & 0.6 \\
$2\left(\mathrm{C}_{4} \mathrm{H}_{4} \mathrm{BH}\right)_{2} \mathrm{Fe}_{2}(\mathrm{CO})_{2} \rightarrow\left(\mathrm{C}_{4} \mathrm{H}_{4} \mathrm{BH}\right)_{2} \mathrm{Fe}_{2}(\mathrm{CO})_{3}+\left(\mathrm{C}_{4} \mathrm{H}_{4} \mathrm{BH}\right)_{2} \mathrm{Fe}_{2}(\mathrm{CO})$ & 17.1 \\
& \\
$2\left(\mathrm{C}_{4} \mathrm{H}_{4} \mathrm{BCH}_{3}\right)_{2} \mathrm{Fe}_{2}(\mathrm{CO})_{4} \rightarrow\left(\mathrm{C}_{4} \mathrm{H}_{4} \mathrm{BCH}_{3}\right)_{2} \mathrm{Fe}_{2}(\mathrm{CO})_{5}+\left(\mathrm{C}_{4} \mathrm{H}_{4} \mathrm{BCH}_{3}\right)_{2} \mathrm{Fe}_{2}(\mathrm{CO})_{3}$ & -1.8 \\
$2\left(\mathrm{C}_{4} \mathrm{H}_{4} \mathrm{BCH}_{3}\right)_{2} \mathrm{Fe}_{2}(\mathrm{CO})_{3} \rightarrow\left(\mathrm{C}_{4} \mathrm{H}_{4} \mathrm{BCH}_{3}\right)_{2} \mathrm{Fe}_{2}(\mathrm{CO})_{4}+\left(\mathrm{C}_{4} \mathrm{H}_{4} \mathrm{BCH}_{3}\right)_{2} \mathrm{Fe}_{2}(\mathrm{CO})_{2}$ & 16.4 \\
$2\left(\mathrm{C}_{4} \mathrm{H}_{4} \mathrm{BCH}_{3}\right)_{2} \mathrm{Fe}_{2}(\mathrm{CO})_{2} \rightarrow\left(\mathrm{C}_{4} \mathrm{H}_{4} \mathrm{BCH}_{3}\right)_{2} \mathrm{Fe}_{2}(\mathrm{CO})_{3}+\left(\mathrm{C}_{4} \mathrm{H}_{4} \mathrm{BCH}_{3}\right)_{2} \mathrm{Fe}_{2}(\mathrm{CO})$ & -11.6 \\
& \\
$2\left[\mathrm{C}_{4} \mathrm{H}_{4} \mathrm{BN}\left(\mathrm{CH}_{3}\right)_{2}\right]_{2} \mathrm{Fe}_{2}(\mathrm{CO})_{4} \rightarrow\left[\mathrm{C}_{4} \mathrm{H}_{4} \mathrm{BN}\left(\mathrm{CH}_{3}\right)_{2}\right]_{2} \mathrm{Fe}_{2}(\mathrm{CO})_{5}+\left[\mathrm{C}_{4} \mathrm{H}_{4} \mathrm{BN}\left(\mathrm{CH}_{3}\right)_{2}\right]_{2} \mathrm{Fe}_{2}(\mathrm{CO})_{3}$ & -4.3 \\
$2\left[\mathrm{C}_{4} \mathrm{H}_{4} \mathrm{BN}\left(\mathrm{CH}_{3}\right)_{2}\right]_{2} \mathrm{Fe}_{2}(\mathrm{CO})_{3} \rightarrow\left[\mathrm{C}_{4} \mathrm{H}_{4} \mathrm{BN}\left(\mathrm{CH}_{3}\right)_{2}\right]_{2} \mathrm{Fe}_{2}(\mathrm{CO})_{4}+\left[\mathrm{C}_{4} \mathrm{H}_{4} \mathrm{BN}\left(\mathrm{CH}_{3}\right)_{2}\right]_{2} \mathrm{Fe}_{2}(\mathrm{CO})_{2}$ & 9.9 \\
$2\left[\mathrm{C}_{4} \mathrm{H}_{4} \mathrm{BN}\left(\mathrm{CH}_{3}\right)_{2}\right]_{2} \mathrm{Fe}_{2}(\mathrm{CO})_{2} \rightarrow\left[\mathrm{C}_{4} \mathrm{H}_{4} \mathrm{BN}\left(\mathrm{CH}_{3}\right)_{2}\right]_{2} \mathrm{Fe}_{2}(\mathrm{CO})_{3}+\left[\mathrm{C}_{4} \mathrm{H}_{4} \mathrm{BN}\left(\mathrm{CH}_{3}\right)_{2}\right]_{2} \mathrm{Fe}_{2}(\mathrm{CO})$ & -5.4 \\
\hline
\end{tabular}

\section{Discussion}

The results reported in this paper allow a comparison of the preferred structures of binuclear borole iron carbonyls $\left(\mathrm{C}_{4} \mathrm{H}_{4} \mathrm{BR}\right)_{2} \mathrm{Fe}_{2}(\mathrm{CO})_{n}(n=5,4,3,2,1)$ having three different type of boron substituents $\left[\mathrm{R}=\mathrm{CH}_{3}, \mathrm{H},\left(\mathrm{CH}_{3}\right)_{2} \mathrm{~N}\right]$ with those of the isoelectronic binuclear cyclopentadienylmanganese carbonyls $[53,54]\left(\mathrm{C}_{5} \mathrm{H}_{5}\right)_{2} \mathrm{Mn}_{2}(\mathrm{CO})_{n}$. For the latter cyclopentadienyl derivatives all of the low energy structures have terminal pentahapto $\eta^{5}-\mathrm{C}_{5} \mathrm{H}_{5}$ cyclopentadienyl rings. The lowest energy structures for the highly unsaturated derivatives $\left(\mathrm{C}_{5} \mathrm{H}_{5}\right)_{2} \mathrm{Mn}_{2}(\mathrm{CO})_{n}(n=2,1)$ have metal-metal multiple bonds of various orders with low energy triplet and higher spin state structures. No examples of agostic bonding of cyclopentadienyl ring hydrogens are found, even in the highly unsaturated $\left(\mathrm{C}_{5} \mathrm{H}_{5}\right)_{2} \mathrm{Mn}_{2}(\mathrm{CO})$. The triply bridged singlet tricarbonyl $\left(\eta^{5}-\mathrm{C}_{5} \mathrm{H}_{5}\right)_{2} \mathrm{Mn}_{2}(\mathrm{CO})_{3}$, which has a short $\mathrm{Mn} \equiv \mathrm{Mn}$ distance suggesting a formal triple bond, appears to be the 
energy sink and has been realized experimentally [10]. The tetracarbonyl and dicarbonyl $\left(\mathrm{C}_{5} \mathrm{H}_{5}\right)_{2} \mathrm{Mn}_{2}(\mathrm{CO})_{n}(n=4,2)$ are predicted to be disfavored relative to disproportionation into $\left(\mathrm{C}_{5} \mathrm{H}_{5}\right)_{2} \mathrm{Mn}_{2}(\mathrm{CO})_{n+1}+\left(\mathrm{C}_{5} \mathrm{H}_{5}\right)_{2} \mathrm{Mn}_{2}(\mathrm{CO})_{n-1}$, where one of the products is the very stable tricarbonyl $\left(\eta^{5}-\mathrm{C}_{5} \mathrm{H}_{5}\right)_{2} \mathrm{Mn}_{2}(\mathrm{CO})_{3}$.

The binuclear borole iron carbonyls $\left(\mathrm{C}_{4} \mathrm{H}_{4} \mathrm{BR}\right)_{2} \mathrm{Fe}_{2}(\mathrm{CO})_{n}(n=5,4,3,2,1)$ differ from the corresponding $\left(\mathrm{C}_{5} \mathrm{H}_{5}\right)_{2} \mathrm{Mn}_{2}(\mathrm{CO})_{n}$ derivatives since the pendant boron substituents $\mathrm{R}\left[=\mathrm{H}, \mathrm{CH}_{3}, \mathrm{~N}\left(\mathrm{CH}_{3}\right)_{2}\right]$ play a role in the bonding of the borole ligand to the $\mathrm{Fe}_{2}$ system in the highly unsaturated derivatives. This makes the normally four-electron donor neutral borole ligand a six-electron donor ligand bridging both metal atoms (Figure 3). For the methylborole derivatives $\left(\mathrm{C}_{4} \mathrm{H}_{4} \mathrm{BCH}_{3}\right)_{2} \mathrm{Fe}_{2}(\mathrm{CO})_{n}(n=5,4,3,2,1)$ one of the hydrogens of the pendant methyl group forms an agostic $\mathrm{C}-\mathrm{H}-\mathrm{Fe} 3 \mathrm{c}-2 \mathrm{e}$ bond with the iron atom not involved in the bonding to the $\pi$ system of the same borole ring. Such agostic $\mathrm{C}-\mathrm{H}-\mathrm{Fe}$ bonding is found in a higher energy triplet state structure of $\left(\mathrm{C}_{4} \mathrm{H}_{4} \mathrm{BCH}_{3}\right)_{2} \mathrm{Fe}_{2}(\mathrm{CO})_{2}$ and in the lowest energy triplet and singlet $\left(\mathrm{C}_{4} \mathrm{H}_{4} \mathrm{BCH}_{3}\right)_{2} \mathrm{Fe}_{2}(\mathrm{CO})$ structures. It does not play a significant role in the thermochemistry of the $\left(\mathrm{C}_{4} \mathrm{H}_{4} \mathrm{BCH}_{3}\right)_{2} \mathrm{Fe}_{2}(\mathrm{CO})_{n} \quad(n=5,4,3,2,1)$ system since the tricarbonyl $\left(\mathrm{C}_{4} \mathrm{H}_{4} \mathrm{BCH}_{3}\right)_{2} \mathrm{Fe}_{2}(\mathrm{CO})_{3}$ is viable with respect to disproportionation whereas the tetracarbonyl and dicarbonyl $\left(\mathrm{C}_{4} \mathrm{H}_{4} \mathrm{BCH}_{3}\right)_{2} \mathrm{Fe}_{2}(\mathrm{CO})_{n}(n=4,2)$ are disfavored with respect to such disproportionation.

The dimethylaminoborole ligand in unsaturated $\left[\mathrm{C}_{4} \mathrm{H}_{4} \mathrm{BN}\left(\mathrm{CH}_{3}\right)_{2}\right]_{2} \mathrm{Fe}_{2}(\mathrm{CO})_{n}$ derivatives can function as a net six-electron donor to the $\mathrm{Fe}_{2}$ system by supplementing the four net electrons from the borole ring with two electrons from the dimethylamino group. These two additional electrons from the dimethylamino group can come either from the nitrogen lone pair or from an agostic $\mathrm{C}-\mathrm{H}-\mathrm{Fe}$ interaction with one of the methyl hydrogen atoms. Both dimethylaminoborole ligands in the lowest energy $\left[\mathrm{C}_{4} \mathrm{H}_{4} \mathrm{BN}\left(\mathrm{CH}_{3}\right)_{2}\right]_{2} \mathrm{Fe}_{2}(\mathrm{CO})_{n}(n=4,3)$ structures function only as net four-electron donors involving only the five atoms of the $\mathrm{C}_{4} \mathrm{~B}$ borole ring. However, slightly higher energy $\left[\mathrm{C}_{4} \mathrm{H}_{4} \mathrm{BN}\left(\mathrm{CH}_{3}\right)_{2}\right]_{2} \mathrm{Fe}_{2}(\mathrm{CO})_{n}(n=4,3)$ structures are found in which dimethylaminoborole is a six-electron donor bridging ligand using electron pairs from the nitrogen atom as well as from the two $\mathrm{C}=\mathrm{C}$ double bonds. For the more highly unsaturated $\left[\mathrm{C}_{4} \mathrm{H}_{4} \mathrm{BN}\left(\mathrm{CH}_{3}\right)_{2}\right]_{2} \mathrm{Fe}_{2}(\mathrm{CO})_{n}(n=2,1)$, low energy singlet $(n=2)$ and triplet $(n=1)$ perpendicular structures are also found with similar bridging six-electron donor dimethylaminoborole ligands. In addition, highly unsaturated $\left[\mathrm{C}_{4} \mathrm{H}_{4} \mathrm{BN}\left(\mathrm{CH}_{3}\right)_{2}\right]_{2} \mathrm{Fe}_{2}(\mathrm{CO})_{n}(n=3,2$, 1) structures are found having agostic hydrogen atoms bridging an iron-carbon bond. However, these bonding possibilities for the pendant dimethylamino group in the $\left[\mathrm{C}_{4} \mathrm{H}_{4} \mathrm{BN}\left(\mathrm{CH}_{3}\right)_{2}\right]_{2} \mathrm{Fe}_{2}(\mathrm{CO})_{n}$ systems do not lead to significant qualitative differences of 


\section{Literature References}

[1] L. H. Long, Prog. Inorg. Chem., 15 (1972). 1-99

[2] R. B. King, Inorganic Chemistry of Main Group Elements, VCH Publishers, 1995, Chapter 8.

[3] R. B. King, M. B. Bisnette, J. Organometal. Chem., 8 (1967) 129.

[4] J. S. Huang, L. F. Dahl, J. Organometal. Chem., 243 (1983) 57.

[5] M. D. Curtis, W. M. Butler, J. Organometal. Chem., 155 (1978) 131.

[6] R. B. King, A. Efraty, W. M. Douglas, J. Organometal. Chem., 60 (1973) 125.

[7] J. Potenza, P. Giordano, D. Mastropaolo, A. Efraty, Inorg. Chem., 13 (1974) 2540.

[8] F. A. Cotton, L. Kruczynski, B. A. Frenz,. J. Organometal. Chem., 160 (1978) 93.

[9] J. C. Huffman, L. N. Lewis, K. G. Caulton, Inorg. Chem., 19 (1980) 2755.

[10] W. A. Herrmann, R. Serrano, J. Weichmann, J. Organometal. Chem., 246 (1983) C57.

[11] J. K. Hoyano, W. A. G. Graham, Chem. Comm., (1982) 27.

[12] W. L. Bailey, D. M. Collins, F. A. Cotton, J. C. Baldwin, J. Organometal. Chem., 165 (1979) 373.

[13] J. P. Blaha, B. E. Bursten, J. C. Dewan, R. B. Frankel, C. L. Randolph, B. A. Wilson, M. S. Wrighton, J. Am. Chem. Soc., 107 (1985) 4561.

[14] G. E. Herberich, W. Boveleth, B. Hessner, D. P. J. Köffer, M. Negele, R. Saive, J. Organometal. Chem., 308 (1986) 153.

[15] G. E. Herberich, W. Boveleth, B. Hessner, M. Hostaler, D. P. J. Köffer, M. Negele, J. Organometal. Chem., 319 (1987) 311.

[16] G. E. Herberich, B. Hessner, M. Negele, J. A. K. Howard, J. Organometal. Chem., 336 (1987) 29.

[17 G. E. Herberich, M. Hostalek, R. Laven, R. Boese, Angew. Chem., 102 (1990) 330.

[18] G. E. Herberich, W. Boveleth, B. Hessner, D. P. J. Köffer, M. Negele, R. Saive, J. Organometal. Chem., 308 (1986) 153.

[19] E. O. Fischer, R. Jira, Z. Naturforsch., 9b (1954) 618.

[20] T. S. Piper, F. A. Cotton, G. Wilkinson, J. Inorg. Nucl. Chem., 1 (1955) 165.

[21] G. F. Emerson, L. Watts, R. Pettit, J. Am. Chem. Soc., 87 (1965) 132.

[22] W. A. Herrmann, R. Serrano, J. Weichmann, J. Organometal. Chem., 246 (1983) C57.

[23] I. Fischler, K. Hildenbrand, E. K. von Gustorf, Angew. Chem., 87 (1975) 35.

[24] W. A. Herrmann, C. E. Barnes, R. Serrano, B. Koumbouris, J. Organometal. Chem., 256 (1983) C30.

[25] J. Chen, S. Chen, L. Zhong, H. Feng, Y. Xie, R. B. King, Inorg. Chem., 50 (2011) 1351.

[26] J. Chen, S. Chen, L. Zhong, H. Feng, Y. Xie, R. B. King, Theor. Chem. Accts., 131 (2012) 1090/1-15.

[27] T. Ziegler; J. Autschbach, Chem. Rev., 105 (2005) 2695.

[28] M. Bühl, H. Kabrede, J. Chem. Theory Comput., 2 (2006) 1282. 
their $\mathrm{CO}$ dissociation behavior and that of the methylborole systems $\left(\mathrm{C}_{4} \mathrm{H}_{4} \mathrm{BCH}_{3}\right)_{2} \mathrm{Fe}_{2}(\mathrm{CO})_{n}$. Thus in both systems the tricarbonyls $\left(\mathrm{C}_{4} \mathrm{H}_{4} \mathrm{BR}\right)_{2} \mathrm{Fe}_{2}(\mathrm{CO})_{3}[\mathrm{R}=$ $\mathrm{CH}_{3}$ and $\left.\left(\mathrm{CH}_{3}\right)_{2} \mathrm{~N}\right]$ are viable with respect to disproportionation into $\left(\mathrm{C}_{4} \mathrm{H}_{4} \mathrm{BR}\right)_{2} \mathrm{Fe}_{2}(\mathrm{CO})_{4}$ and $\left(\mathrm{C}_{4} \mathrm{H}_{4} \mathrm{BR}\right)_{2} \mathrm{Fe}_{2}(\mathrm{CO})_{2}$ whereas the tetracarbonyls and dicarbonyls $\left(\mathrm{C}_{4} \mathrm{H}_{4} \mathrm{BR}\right)_{2} \mathrm{Fe}_{2}(\mathrm{CO})_{n}$ $(n=4,2)$ are disfavored relative to disproportionation into $\left(\mathrm{C}_{4} \mathrm{H}_{4} \mathrm{BR}\right)_{2} \mathrm{Fe}_{2}(\mathrm{CO})_{n+1}+$ $\left(\mathrm{C}_{4} \mathrm{H}_{4} \mathrm{BR}\right)_{2} \mathrm{Fe}_{2}(\mathrm{CO})_{n-1}$ (Table 7). Furthermore, the lowest-energy structures of the tricarbonyls $\left(\mathrm{C}_{4} \mathrm{H}_{4} \mathrm{BR}\right)_{2} \mathrm{Fe}_{2}(\mathrm{CO})_{3}$ are triply bridged structures with $\mathrm{Fe} \equiv \mathrm{Fe}$ distances of $\sim 2.2 \AA$ corresponding to formal triple bonds similar to the experimental structure $\left(\eta^{5}-\mathrm{Me}_{5} \mathrm{C}_{5}\right)_{2} \mathrm{Mn}_{2}(\mu-\mathrm{CO})_{3}$ with an $\mathrm{Mn} \equiv \mathrm{Mn}$ distance of $2.17 \AA$ as determined by X-ray crystallography [55].

The relative stabilities of the $\left(\mathrm{C}_{4} \mathrm{H}_{4} \mathrm{BH}\right)_{2} \mathrm{Fe}_{2}(\mathrm{CO})_{n}$ systems appear to be different from those of the previously reported $\left(\mathrm{C}_{4} \mathrm{H}_{4} \mathrm{BR}\right)_{2} \mathrm{Fe}_{2}(\mathrm{CO})_{n}$ systems $\left[\mathrm{R}=\mathrm{CH}_{3},\left(\mathrm{CH}_{3}\right)_{2} \mathrm{~N}\right]$. In particular, disproportionation of the tricarbonyl $\left(\mathrm{C}_{4} \mathrm{H}_{4} \mathrm{BH}\right)_{2} \mathrm{Fe}_{2}(\mathrm{CO})_{3}$ into $\left(\mathrm{C}_{4} \mathrm{H}_{4} \mathrm{BH}\right)_{2} \mathrm{Fe}_{2}(\mathrm{CO})_{4}+\left(\mathrm{C}_{4} \mathrm{H}_{4} \mathrm{BH}\right)_{2} \mathrm{Fe}_{2}(\mathrm{CO})_{2}$ is essentially thermoneutral. However, the dicarbonyl $\left(\mathrm{C}_{4} \mathrm{H}_{4} \mathrm{BH}\right)_{2} \mathrm{Fe}_{2}(\mathrm{CO})_{2}$ appears to be viable towards an analogous disproportionation. We believe that this might relate to the stabilization of the lowest energy $\left(\mathrm{C}_{4} \mathrm{H}_{4} \mathrm{BH}\right)_{2} \mathrm{Fe}_{2}(\mathrm{CO})_{2}$ structure $\mathbf{2 Q - 2}$ by the B-H-Fe 3c-2e bond.

Acknowledgment. This research was supported by Funds for Sichuan Distinguished Scientists (Grant No. 2015JQ0042), Funds for the Youth Innovation Team of the Education Department of Sichuan Province (Grant No. 14TD0013) in China, and the U. S. National Science Foundation (Grant CHE-1057466). 
[29] M. Brynda, L. Gagliardi, P. O. Widmark, P. P. Power, B. O. Roos, Angew. Chem. Int. Ed., 45 (2006) 3804.

[30] N. Sieffert, M. Bühl, J. Am. Chem. Soc., 132 (2010) 8056.

[31] P. Schyman, W. Lai, H. Chen, Y.Wang, S. Shaik, J. Am. Chem. Soc., 133 (2011) 7977.

[32] R. D. Adams, W. C. Pearl, Y. O. Wong, Q. Zhang, M. B. Hall, J. R. Walensky, J. Am. Chem. Soc., 133 (2011) 12994.

[33] R. Lonsdale, J. Olah, A. J. Mulholland, J. A. Harvey, J. Am. Chem. Soc., 133 (2011) 15464.

[34] A. D. Becke, J. Chem. Phys., 98 (1993) 5648.

[35] C. Lee, W. Yang, R.G. Parr, Phys. Rev. B 37 (1988) 785.

[36] A. D. Becke, Phys. Rev. A 38 (1988) 3098.

[37] J. P. Perdew, Phys. Rev. B 33 (1986) 8822.

[38] M. Reiher, O. Salomon, B. A. Hess, Theor. Chem. Acc., 107 (2001) 48.

[39] J. N. Harvey, Structure and Bonding, 112 (2004) 151.

[40] O. Salomon, M. Reiher, B. A. Hess. J. Chem. Phys., 117 (2002) 4729.

[41] V. Jonas, W. Thiel, J. Phys. Chem., 102 (1995) 8474.

[42] I. Silaghi-Dumitrescu, T .E. Bitterwolf, R. B. King, J. Am. Chem. Soc., 128 (2006) 5342.

[43] M. K. Assefa, J. L. Devera, A. D. Brathwaite, J. D. Mosley, M. A. Duncan, Chem. Phys. Lett., 640 (2015) 175.

[44] T. H. Dunning, J. Chem. Phys., 53 (1970) 2823.

[45] S. Huzinaga, J. Chem. Phys., 42 (1965) 1293.

[46] A. J. H. Wachters, J. Chem. Phys., 52 (1970) 1033.

[47] D. M. Hood, R. M. Pitzer, H. F. Schaefer, J. Chem. Phys., 71 (1979) 705.

[48] M. J. Frisch, et al. Gaussian 09, Revision A.02; Gaussian, Inc., Wallingford CT, (2009).

[49] J. V. Caspar, T. J. Meyer, J. Am. Chem. Soc., 102 (1980) 7794.

[50] R. H. Hooker, K. A. Mahmoud, A. J. Rest, Chem. Commun., (1983) 1022.

[51] A. F. Hepp, J. P. Blaha, C. Lewis, M. S. Wrighton, M. S. Organometallics, 3 (1984) 174.

[52] L. S. Sunderlin, D. Wang, R. R. Squires, J. Am. Chem. Soc., 115 (1993) 12060.

[53] X. Zhang, Q.-s. Li, Y. X.; R. B. King, H. F. Schaefer, Organometallics, 27 (2008) 61.

[54] X. Zhang, Q-.s. Li, Y. Xie, R. B. King, H. F. Schaefer, J. Mol. Struct., 890 (2008) 184.

[55] I. Bernal, J. D. Korp, W. A. Hermann, R. Serrano, Chem. Ber., 117 (1984) 434. 